\title{
LEGAL TECHNIQUES FOR COMBATING LOAN SHARKS ${ }^{1}$
}

\author{
Charles S. Kelly*
}

The ultimate objective of law enforcement in the small loan field is the permanent suppression of the business of making illegal small loans rather than the imposition of penalties upon isolated instances of law breaking. The value of particular remedies and the wisdom of bringing criminal prosecutions or civil actions of particular types depend upon the degree in which they tend to achieve this result.

Permanent suppression of the illegal small loan business will be aided or retarded in any particular state according to the number and variety of the legal techniques available for the purpose. The available facilities of this nature differ widely in the various states. In those states which have enacted adequate small loan laws ${ }^{2}$ permanent suppression may be accomplished. ${ }^{3}$ But, inasmuch as illegal lending naturally flourishes most vigorously in states where effective small loan laws do not exist, its suppression must necessarily be accomplished to a considerable extent by the use of remedies other than those provided by small loan laws. The number and variety of these independent remedies are sufficient in most states to make possible substantial curbing if not permanent elimination of illegal lending when employed with a discrimination growing out of an understanding of the nature of the problem to be solved.

- LL.B., 1925, University of Minnesota. Member of the Illinois and Minnesota bars. Counsel, Household Finance Corporation.

The author wishes to acknowledge the assistance of Robert A. Crane of the lllinois Bar in the preparation of this article.

${ }^{1}$ Due to limitations of space, citations to particular statutes and other documentary material have been omitted in some cases. Such citations and more complete treatment of many matters herein touched upon may be found in one or more of the following: Camalier, Personal Finance Laws (Am. Ass'n of Personal Finance Cos., 1938); Hubachex, Annotations ON Small LonN Laws (Russell Sage Foundation, 1938); Young, Personal Finance Companies and Their Credit Practices, (Nat. Bur. Econ. Res. 1940) 33-35; Horack, A Survey of the General Usury Laws, supra p. 36 and the accompanying chart, pp. 48.53; Report of the Special Committee of the International Association of Governmental Labor Officials on the Enforcement of Laws Against Loan Sharks (U. S. Dep't Labor, Bur. Labor Stesistics, 1940), summarized without citations in (1940) 50 MoN. LAs. REv. ro5r.

'A majority of the states have adequate small loan laws. They are cited and evaluated in other articles in this symposium.

${ }^{8}$ No kind or amount of law enforcement will stop the borrowing of small sums of money at high and illegal rates of charge unless legitimate sources of loans are provided for classes of borrowers now served only by loan sharks. This necessitates the authorization of charges which are sufficiently high to permit such loans to yield profits, but which nevertheless may be a small fraction of those now charged by loan sharks. Hence, the discussion of effective law enforcement in this paper. is qualified by recognition of the fact that permanent solution of the small loan problem requires establishment of legitimate sources of credit under regulatory laws such as the small loan laws. 


\section{Nature of the Problem}

It would be natural to inquire why the borrower cannot protect himself by invoking whatever rights and defenses the usury laws give him. If a loan contract is usurious, it is often assumed without question that the usury law will provide a sufficient remedy. In practice, usury laws have failed to do so in this field of lending. ${ }^{4}$

The lending of small sums illegally to wage earners as a substantial business is of relatively recent origin. ${ }^{5}$ Usury laws, which have existed for more than 300 years without any substantial change in form, do not provide a means to cope with this new problem. Borrowers of small sums do not possess the reserves of money necessary to pay lawyers or the time to appear in court to defend themselves. They are dependent upon their daily wages for a living. Usury laws were designed to regulate relations between lenders and borrowers who stand in something approaching an equal bargaining position. The rights and remedies provided by these laws are mild in nature and they do not become effective except as the result of affirmative action by the borrower or someone acting on his behalf.

There is a general realization that the relations between wage earner debtors and those from whom they borrow have created a social problem. But there seems to be only limited public appreciation of the relative helplessness of the borrower and the consequent necessity that representatives of the public interest themselves on his behalf if the public interest is to be adequately protected and a solution of this social problem achieved. ${ }^{6}$

\footnotetext{
- In granting injunctive relief at the suit of the state against the continuation of a usurious wage buying scheme, the Supreme Court of Kansas in the following language held the remedies of the individual borrowers under the usury law were inadequate: "But, according to plaintiffs" allegations, the truth of which is conceded by the demurrers, this statute is systematically set at naught by the defendants. Between money lender and borrower, of course, it is altogether ineffective until invoked in some lawsuit. And according to the plaintiffs' allegations such a lawsuit will not arise once in every hundred times the usurious toll is taken from the wages of his victim. The wage earner has no time to attend court nor means to employ a lawyer to invole the defense to the usurer's claim accorded by this statute. He must carn wages every working day to support his family. If garnishment proceedings are instituted which will bring his employer into court on matters of no concern to that employer, the unfortunate debtor is discharged. This dread consequence to the debtor can only be avoided by continued submission to defendants' usurious exactions.

". . . In the situation portrayed by plaintiffs, it is perfectly obvious that for the hundreds of indigent debtors held in financial peonage by defendants the remedy supplied by law is pitifully inadequate; ..." State ex rel. Smith v. MeMahon, 128 Kan. 772, 280 Pac. 906, 66 A. L. R. 1072 (1929).

- See Nugent, Consumer Credit and Economic Stability (Russell Sage Foundation, 1939) c. III.

- The principles underlying the right of intervention of public authorities for the purpose of protecting the public welfare have been best stated by the United States Supreme Court in the landmark case of In re Debs as follows: "Every government, entrusted by the very terms of its being with powers and duties to be exercised and discharged for the general welfarc, has a right to apply to its own courts for any proper assistance in the exercise of the one and the discharge of the other. . . The obligations which it is under to promote the interest of all and to prevent the wrongdoing of one resulting in injury to the general welfare is often of itself sufficient to give it a standing in court." I58 U. S. 564,584 (1895).

The Supreme Court of Tennessec has applied these same principles to the loan shark situation in the following language: "The near relation between the economic and social structure and impecunious borrowers is such as to authorize measures for the protection of that helpless class from the consequences of their stupidity, folly, or helplessness. Their injurious exploitation by persons who lend money is calculated to increase poverty and spread mendicancy and so injure the public." State ex rel. v. Family Loan Co., I67 Tenn. 654, 73 S. W. (2d) 167 (1934).
} 
This helplessness of the borrower arises from the extreme disparity in the relative economic positions of lenders and borrowers of small sums and the practical inability of such borrowers to protect themselves after the contracts have been signed. ${ }^{7}$ In this respect the wage earner borrower is distinguishable from the typical borrower for commercial purposes, who is sufficiently strong economically to avoid being seriously imposed upon. The typical consumer borrower is pathetically incapable of securing a fair bargain at the outset. He is usually ignorant of the rights accorded him by law after he has become indebted. He lacks the time and money necessary for an effective insistence upon those rights of which he may be aware. He is constantly reminded by the lender that any defensive move on his part will be attended with disastrous consequences to himself. The lender can and will retaliate by garnisheeing his wages (which often results in loss of his job), ${ }^{8}$ by seizing his property, by injuring his reputation and peace of mind through repeated dunning visits, letters, and telephone calls, not only to himself but to his friends, relatives, and employer, and by innumerable other methods. He must even fear the loss of the source of credit available through the loan shark. His lack of information, his inability to fight, and his precarious economic position make yielding to the usurer's demands appear preferable to facing the seemingly overwhelming consequences of defiance.?

The weakness of borrowers has been viciously exploited by the modern loan shark. ${ }^{10}$ As a class, these lenders are notorious for their continued and deliberate defiance of law and their disregard for the consequences of their anti-social practices. In many communities their operations have created such a drain upon the resources of large numbers of wage earners that the general standard of living has been materially reduced. The degenerative consequences of such situations concern not only the individuals involved, but the entire community. ${ }^{11}$ In view of these consequences,

\footnotetext{
$\tau$ "In the very nature of things, such borrowers are frequently illiterate, often inexperienced, and usually as a result of ignorance, inexperience, poverty, or necessity incapable of defending themselves against wrongful, oppressive, fraudulent, or extortionate exactions by the lender." Liberty Finance Co. v. Catterton, I6I Md. 650, 158 Atl. I6 (1932). See also In re Home Discount Company, 147 Fed. 538 (D. C. Ala., 1906); Shaw v. Fox, 55 S. W. (2d) II (Ky. Ct. App., I932); Commonwealth v. Donoghue, 250 Ky. 343, 63 S. W. (2d) 3, 89 A. L. R. 819 (1933); Ravitz v. Steurele, 257 Ky. 108, 77 S. W. (2d) 360 (Ct. App., 1934); State ex rel. v. Family Loan Co., supra note 6; Cotton v. Cooper, 209 S. W. 135 (Tex. Com. App., 1919).

${ }^{8}$ See In re Home Discount Co., and Cotton v. Cooper, supra note 7.

- See an article in the Atlanta Journal, Nov. 24, 1940, in which conditions caused by loan, sharks in Georgia are described. Quoting from a report made by Attorney General Ellis Arnall to Governor Rivers, the article contains the following statement: "The public generally has been reluctant to co-operate because most victims of the 'loan shark racket' apparently are afraid to disclose facts for fear that interest rates will be increased on their obligations or that they will be 'blacklisted' and also on account of the policy of employers firing their employes when demand is made on them to pay their employes' financial obligations. Many anonymous complaints which are of no value as evidence indicate this fear on the part of victims, and other victims, while giving information, refuse to become witnesses, execute affidavits or testify in an action against the loan company." See note 6 supra, and Birkhead, Collection Tactics of Illegal Lenders, supra p. 78.

${ }^{10}$ The term "loan shark" in recent years has come to mean a money lender who makes illegally high charges to necessitous, ignorant, or gullible wage earners and other persons of moderate income. This term and "illegal lender" are used in that sense in this article.

12 Supra note 9. The article again quotes from the Attorney General's report as follows: "It is also found that the method of operation employed by such companies is undesirable and detrimental to the public welfare."
} 
it is not possible to conclude that such lenders justify their existence by contributing a valuable service; to the contrary their excesses add to rather than subtract from the sum total of economic maladjustment. ${ }^{12}$

The suppression of abuses in the field of consumer lending is thus a matter of proper and necessary public concern just as is the suppression of crime or of other anti-social conduct. Public authorities have a consequent duty to take whatever action may be necessary to minimize these abuses. As has been well said:

"... the ruling ... that the exaction of usury is a mere contractual matter of no concern to anybody but the parties themselves, is imperatively in need of revision in the light of the complex social and economic conditions brought about by the industrial development in the last century since that doctrine was announced."13

Adequate accomplishment of this duty on the part of public authorities depends upon an understanding of the many devices used by loan sharks to escape the impact of usury and other laws. The usurious character of loan shark contracts is almost invariably concealed. ${ }^{14}$

"If an express stipulation for the repayment of the sum advanced be indispensable to the existence of usury, he must be a bungler indeed, who frames his contract on such terms as to expose himself ta the penalties of the law."15

Many of the innumerable devices used for this purpose are designed to conceal the fact that the particular transaction is a loan of money. A favorite is the device of casting the loan in the form of a purchase or sale of wages, merchandise certificates, insurance policies, or various other kinds of property, the purpose being to require treatment of the profit from the transaction as resulting from the purchase or sale rather than as interest. These devices fail when the true nature and intent of the transaction is demonstrated, inasmuch as courts will disregard the pretended form and apply the usury laws if the transaction is in fact a loan. ${ }^{16}$ Sometimes such devices also run afoul of laws other than those regulating interest, such as those concerning insurance or the sale of securities. One such device has been held to violate the Kansas Trading Stamp Act. ${ }^{17}$

\footnotetext{
${ }^{12}$ See article by Joseph A. Padway, Counsel, American Federation of Labor, Minnesote Supreme Court Deals a Death Blow to the "Loan Shark," (1939) 46 AM. Federationist 975.

${ }^{13}$ State ex rel. Smith v. McMahon, supra note 4. See also note 6, supra, and Georgia v. Tennessee Copper Co., 206 U. S. 230 (1907); U. S. v. American Bond \& Mortgage Co., 31 F. (2d) 448 (D. C. Ill. 1929), aff'd, without discussion of this point, 52 F. (2d) 318 (C. C. A. 7th, 1931); People v. Tool, 35 Colo. 225, 86 Pac. 224, 6 L. R. A. (N.s.) 822 (xg05); Trust Co. of Georgia v. State, rog Ga. 736, 36 S. E. 823 (1900); State v. Lindsey, 85 Kan. 79, I16 Pac. 207 (I9II); Commonwealth v. McGovern, II6 Ky. 212, 75 S. W. 26r (1903); Repass v. Commonwealth, I3I Ky. 807, II5 S. W. Ii3I (1909) 21 L. R. A. (N.s.) 836.(1909); Kentucky State Board of Dental Examiners v. Payne, 213 Ky. 382, 281 S. W. I88 (1926); State v. Pacific Express Co., 80 Neb. 823, 115 N. W. 619 (1909); State v. C. B. \& Q. R. R., 88 Neb. 669, 130 N. W. 295 (191I); State ex rel. McCarter v. Firemen's Insurance Co., 74 N. J. Eq. 372, 73 Atl. 80 (1909); State v. Newark Milk Co., 118 N. J. Eq. 504, 179 Atl. I16 (1935).

${ }^{24}$ For a discussion of evasive devices see HuвAcrek, op. cit. supra note I, pt. III; and Collins, Evasion and Avoidance of Usury Laws, supra p. 54.

${ }^{15}$ Chief Justice Marshall in Scott v. Lloyd, 34 U. S. (g Pet.) 418 ( 1835 ).

${ }^{20}$ HubacheK, op. cit. supra note $\mathrm{I}$, at 152 et seq.

${ }^{17}$ State v. Buchman, ror P. (2d) 885 (Sup. Ct. Kan. 1940).
} 
Where the transaction is admittedly a loan, other devices are employed to conceal the fact that all or a part of the charges paid by the borrower or received by the lender are interest. Such concealment is often attempted, for example, by disguising the excessive charges as fees for supposed brokerage services performed by purportedly independent third persons who actually serve the lender, or by taking two notes (one for the actual principal with legal interest on which suit may be brought, and the other for the excessive portion of the charges), or by incorporating in the ostensible principal of the notes amounts representing excessive.charges.

A current scheme involving attempted concealment of the nature of the charge is the device of providing in consideration of a special "hazard" fee for a release of the borrower's obligation to repay in the event of the occurrence of a specified contingeñcy, such as the borrower's death or the destruction of collateral security. This device seeks to take advantage of the principle that interest limitations do not apply if a loan is not repayable in all events. ${ }^{18}$ But it fails to accomplish this purpose if the occurrence of the contingency is so urlikely or the contingency itself is so unrelated to the hazards normally incident to debtor-creditor relationships as to render the contingency illusory. The Pacific Finance Corporation operating in the state of New York was recently required by a court decree to refund to borrowers approximately $\$ 250,000$ of interest overcharges resulting from the use of this device. ${ }^{19}$ Such contracts may also fall within the statutory definitions of insurance contracts and render the lender subject to penalties provided for engaging in the insurance business without a license. ${ }^{20}$

Still other less ingenious devices are designed to conceal acts of outright fraud or chicanery, such as short changing the borrower at the time the principal is advanced or falsifying the records of periods or amounts involved.

Any given contract may include more than one of these devices. Courts will always receive oral evidence to prove the usurious or other illegal character of any contract of loan, regardless of the method adopted to conceal the fact of illegality. ${ }^{21}$

"... where the contract is in truth for the borrowing and lending of money, no form which can be given to it will free it from the taint of usury, if more than legal interest be secured. ...

"Courts, therefore, perceived the necessity of disregarding the form, and examining into the real nature of the transaction. If that be in fact a loan, no shift or device will protect it."22

${ }^{18}$ HUBACHeK, op. cit. supra note 1 , at 163

${ }^{10}$ See N. Y. Times, Apr. 23, I940; N. Y. Herald Tribune, May 3, 1940; an unreported decree entered by Justice Miller in People v. Pacific Finance Corporation (Sup. Ct., N. Y., Apr. 22, 1940); and Bennett and Heffner, The Campaign Against Auto Loan Usurers in New York State (Conf. on Personal Finance Law, 1940). The Pacific Finance Corporation referred to should not be confused with the company of the same name operating in California or other identically named organizations operating elsewhere.

${ }_{20}$ See Annotations and the cases therein cited in 35 A. L. R. 1039,63 A. L. R. 726, and 100 A. L. R. 1454, and the close cases of Att'y Gen. ex rel. Monk v. Osgood Co., 249 Mass. 473, 144 N. E. 371, 35 A. L. R. 1037 (1924); M. K. \& T. Trust Co. v. McLachlen, 59 Minn. 468, 61 N. W. 560 (1894); and Ollendorff Watch Co. v. Pink, 279 N. Y. 32, 17 N. E. (2d)' 676 (1938).

${ }^{21}$ HubacheK, op. cit. supra note I at 152 et seq.

ss Supra note 15 . 
Proof of the essentially usurious character of such devices is simplified when they have been repeatedly used. Isolated transactions of these unusual types may be bona fide and based on expedient reasons but there can seldom be any reason to resort continuously to such cumbersome methods except to avoid usury laws. Thus the mere showing of continuity will be accepted as evidence of the real intention of the lender. ${ }^{23}$

Evasive devices of loan sharks are not limited to contractual manipulations but they extend also to the adoption of forms of business organization and methods of doing business adapted for the same protective purposes. Loan shark organizations are carefully planned to minimize the possibility of effective punitive action. They are frequently interstate in character, thus facilitating prompt transfer of persons and assets from state to state to minimize the possibility of arrest, sequestration of assets, and service of civil process. The identity of the principals is often concealed and business is carried on through agents, perhaps operating under unregistered trade names. When information as to the ownership or personnel of the business must be recorded publicly, the names of dummy owners or managers are used.

In proceeding against loan sharks prompt and decisive action is necessary to prevent nullification of efforts through removals across state lines. Inasmuch as it is usually futile to prosecute subordinates, who are often well paid to submit to punishment, it is necessary to determine the true identity of the principals and to bring pressure to bear upon them directly.

\section{Legal TechntQues}

In order to achieve a maximum degree of effectiveness with the greatest economy of time and money, law enforcement efforts should be based upon a use of those of the following legal techniques which give the greatest promise of putting an immediate and permanent stop to the activities of the loan shark. The typical loan shark continues in business solely to make money. He will go out of business just as soon as the prospect of profit disappears or the personal danger of criminal prosecution and imprisonment becomes so great as to overcome the desire for profit. Consequently, the use of remedies which tend to eliminate profits as well as those which tend to place the loan shark personally in criminal jeopardy will most effectively accomplish the suppression of illegal lending.

The statutes most frequently violated by loan sharks are, of course, those regulating the rights of debtors and creditors. In the absence of statute, loan contracts are not limited as to permissible rates of charge. ${ }^{24}$ Nearly every state, however, has enacted statutes dealing with interest limitations and other aspects of money lending. These include ( $I$ ) usury laws, (2) wage assignment laws, (3) chattel mortgage laws, (4) property and wage exemption laws, (5) -small loan laws, and (6) miscellaneous laws regulating various particular types of lending, such as credit union laws, industrial banking laws, and general banking laws. In special circumstances of the kinds

28 Hubackex, op. cit. supra note I, at 154 .

2427 R. C. L. 203. 
previously mentioned, other laws, such as insurance laws, security laws, and trading stamp laws, are applicable. Not all of these laws are in force in every state, but some at least are in effect in practically every state.

The usury laws not only fix maximum rates of interest but usually prescribe remedies available to the victim. These remedies are designed (a) to relieve the borrower from the necessity of paying interest in excess of the legal rate 25 or any interest whatever in some instances; ${ }^{26}$ (b) to permit the borrower to offset the amount of excessive payments made by him, or multiples thereof, against the amount otherwise recoverable by the lender $;^{27}$ (c) to permit the borrower to recover excessive interest payments made by him, sometimes with an additional increment of one or two times the amount of the excessive payments; ${ }^{28}$ and (d) to permit the borrower to recover principal payments made by him. ${ }^{29}$ In some states, if excessive charges have been contracted for or received, the entire contract of loan is rendered void, both as to principal and interest. ${ }^{30} \mathrm{~A}$ few statutes authorize equitable relief at the instance of the borrower, ${ }^{31}$ which may sometimes be obtained in the absence of statutory authorization where the excesses of the lender have been so great as to warrant the interposition of equity. ${ }^{32}$ Some statutes permit the granting of relief similar to declaratory judgment upon the petition of the borrower ${ }^{33}$ and this kind of relief may sometimes be obtained under independent statutes or procedures. ${ }^{34}$ Some states impose criminal penalties upon the taking of usury. ${ }^{35}$

Where the common device of casting loans in the form of wage purchases is used, or where wage assignments are taken as security, statutes relating to wage assignments come into play. ${ }^{36}$ They customarily impose various limitations upon the amount of wages subject to effective assignment and upon the formalities of such assignments, as well as prescribing the time within which assignments must be filed with employers in order to be valid. Illegal assignments are often rendered totally void, and are sometimes attended with criminal consequences. ${ }^{37}$ In some states loan W. Va.

${ }^{25}$ See the statutes of Del., Ind., Kan., Ky., La., Md., Mass., Mo., Nev., Ohio, Pa., Tenn., Vt., and

${ }^{28}$ See the statutes of Ala., Ariz., Calif., D. C., Fla., Ga., Hawaii, Idaho, Ill., Iowa, Mich., Miss., Mont, Neb., N. J., N. Mex., N. C., N. D., Okla.; S. C., S. D., Tex., Va., Wash., Wis., and Wyo.

${ }^{27}$ See the statutes of Ala., Ariz., D. C., Ga., Hawaii, Ind,, Kan., Mass,, Mo., Neb., N. J., N. Mex,, N. C., Ohio, Okla., S. C., S. D., Wash., and Wyo.

${ }^{28}$ See the statutes of Ariz., Calif., Del., D. C., Fla., Ga., Idaho, Kan., Ky., La., Md., Minn., Miss., Mo., Mont., N. Mex., N. Y., N. C., N. D., Okla., Pa., S. C., S. D., Tenn., Tex., Utah, Vt., Va., W. Va., and Wis.

${ }^{20}$ See the statutes of Miss. (where the rate of interest exceeds $20 \%$ per annum), and Utah.

${ }^{80} \mathrm{Sec}$ the statutes of Ark., Conn., Fla. (where the rate of interest exceeds $25 \%$ per annum), Minn,, Miss. (where the rate of interest exceeds $20 \%$ per annum), N. Y., and Utah.

${ }^{81}$ See, for example, the statutes of Ark., Minn., N. Y., and Utah.

${ }^{32}$ See 66 Corpus Juris 265 et seq., and Horner v. Nitsch, 103 Md. 498, 63 Atl. 1052 (1906).

ss See the statutes of Mich., Minn., N. Y., and Utah.

34 See Borchard, Declaratory Judgments (1934) especially at 334 et seq.

${ }^{35}$ See the statutes of Calif., Conn., Fla., Ga., Hawaii, Iowa, Mo., N. Mex., N. C., N. D., S. C., S. D., Utah, Wis., and Wyo.

${ }^{\text {so }}$ In the absence of statute, assignments of unearned wages with certain limitations may be void at coinmon law. See 6 Corpus JuRis Sec. 1062 et seq.

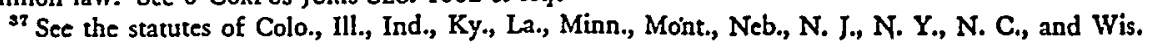


contracts secured by illegal wage assignments are rendered void. ${ }^{38}$ Special interest limitations are sometimes imposed upon loans secured by wage assignments. ${ }^{32}$ The small loan laws of most states impose comparable restrictions upon wage assignments and treat wage purchases and the profit thereon as loans and interest for purposes of regulation. ${ }^{40}$

Chattel mortgage laws ${ }^{41}$ frequently contain limitations on the manner of execution and the types of property subject to liens of this nature. They may also require the consent of the mortgagor's spouse ${ }^{42}$ and judicial foreclosure on certain kinds of property such as household furniture. ${ }^{43}$

Property exemption laws are generally designed to eliminate necessary tools and household equipment from judicial seizure. In some states such property may not become the subject of a chattel mortgage. Usually in addition to such laws there are wage exemption laws which prohibit assignment or judicial seizure of a designated portion of earnings deemed necessary to maintain life.

Small loan laws perform an invaluable service by providing the legal setting essential to the establishment of a legitimate source of credit for wage earner borrowers, thus eliminating the necessity to resort to loan sharks. Of more immediate importance with respect to law enforcement, however, are the provisions which impose criminal penalties upon the taking of excessive charges and other violations, those which invalidate contracts of loan involving violations, and those which impose responsibility for administration and enforcement upon a designated public official. By providing drastic criminal and civil penalties and centralized responsibility for enforcement, they not only tend to restrain the loan shark through fear of the severe consequences of-infractions of the law, but they insure that the penalties will actually be imposed through the efforts of the official whose duty it is to enforce the penal provisions.

Banking laws, building and loan association laws, credit union laws, and industrial banking laws, except insofar as they create legitimate competitive sources of credit, usually contain little or nothing bearing upon the loan shark situation.

The foregoing laws provide in the main for individual remedies available to the borrowers. Despite their ineffectiveness when their assertion is left to the efforts of individual victims, they may be rendered highly effective by the activities of agencies such as legal aid societies, labor unions, bar associations, newspapers, better business bureaus, and comparable organizations, ${ }^{44}$ willing to aid in asserting them on behalf

${ }^{38}$ See the statutes of Colo., Ind., La., and Mont.

${ }^{80}$ See the statutes of Colo., Ga., Ind., La., Md., Mont., N. J., and Tex.

${ }^{10}$ See Hubachex, op. cit. supra, note I, at I03-I IO.

1 See Jones, Chattel Mortgages and Conditionai, Sales (Bowers Ed. 1933).

"See the statutes of Colo., Ill., Neb., N. H., N. J., N. C., N. D., and Ohio.

${ }^{13} \mathrm{Sec}$ the statutes of Ill., Ind., and Ohio.

"See, for cxample, with respect to: (a) legal aid society-Atlanta Constitution, May 24, I929; (b) labor union-Report of the Executive Council of the American Federation of Labor to the Sixtieth Annual Convention (New Orleans, Nov. 15, 1940) 153; (c) bar association-Report of Committee of Savannah (Ga.) Bar Association Appointed to Investigate Small Loan Business in that City (Am. Ass'n of Personal Finance Cos., 1939); (d) newspaper-Louisville Herald-Post, Oct. 24, 1933; (e) better business 
of large numbers of borrowers. ${ }^{45}$ Through economies resulting from handling of cases in volume and through the selection of procedures permitting determination of the rights of numerous borrowers in a single action, such efforts may sometimes have "wholesale" results.

In addition to the criminal provisions of the usury, wage assignment, and small loan laws, other criminal laws are applicable to the activities of loan sharks. Such remedies are of course available to the state on its own behalf. All criminal prosecutions have a unique advantage in loan shark matters. When the state may act in its own capacity, the original inertia resulting from the disadvantageous circumstances of the borrower is eliminated, as well as the hazard that he will be coerced into dismissing his suit, once it has been instituted. Furthermore, a stigma results from a criminal prosecution and conviction and not from a civil suit by a borrower. This stigma, together with the risk of fine and imprisonment, constitutes a more effective deterrent to a calloused loan shark than many civil penalties, especially when he may expect vigorous and unrelenting efforts on the part of prosecuting officials.

A combination of persons to obtain usurious exactions has been held to constitute the common law crime of conspiracy. ${ }^{46}$ This remedy is available in other states which recognize this common law crime, and the same result could probably be obtained in some 25 other states and territories ${ }^{47}$ where the crime is broadly defined by statute. The wide range of evidence admissible in conspiracy prosecutions makes this procedure specially attractive from a practical point of view.

A place of business where usurious agreements are habitually negotiated may be a disorderly house. As early as 1905 the public prosecutor of New Jersey prosecuted loan sharks under the disorderly house statute and obtained at least two convictions. ${ }^{48}$ This remedy is no doubt available in many other states.

bureau-Special Report on Investigation of High Rate Loan Companies in Minneapolis, July 1, 1938 to July X, x939, (Better Business Bureau of Minneapolis, Inc.); ( $f$ ) chamber of commerce: Charlotte (N. C.) Sunday Observer, Nov. 20, 1932; (g) states attorney-Chicago Daily News and Chicago Evening Post, Apr. I, 1933); (h) chief of police-Waco (Tex.) Times-Herald, Feb. 27, 1928; (i) railroad corporationThe Kentucky Post (Cincinnati Ed.), Apr. 2r, r933.

${ }^{15}$ This aspect of the matter is treated at length in the Report of the Special Committee of the International Association of Governmental Labor Officials, supra note $\mathrm{I}$.

${ }^{10}$ Commonwealth v. Donoghue, supra note 7. See also State v. Continental Purchasing Company, 119 N. J. L. 257, I95 Atl. 827 (Sup. Ct., 1938), aff'd per curiam, 121 N. J. L. 76, I Atl. (2d) 377 (1938), where a combination to purchase obligations to pay money and to force their payment by means of undue coercion was held to constitute a common law criminal conspiracy.

The appropriateness of this remedy is demonstrated by the following language from the latter opinion, where, in refuting the contention that the indictment failed to set forth an indictable offense because the objective and the means of accomplishment of the conspiracy were not criminal, it was said: "It is not essential to criminal liability under the common law that the acts contemplated should constitute a criminal offense for which, without the element of conspiracy, one alone could be indicted. The true rule is that all such acts as have the necessary tendency to prejudice the public or to injure or oppress individuals by unjustly subjecting them to the power of the conspirators are sufficiently tainted with the quality of unlawfulness to satisfy the requirements as to conspiracy."

"Ala., Ariz., Ark., Calif., Colo., Conn., Fla., Hawaii, Idaho, Iowa, Me., Minn., Miss,, Mo., Mont., Nev. N. J., N. Y., N. D., Okla., Pa., S. D., Tenn., Wash., and Wis.

is State v. Diamant, 73 N. J. L. 13I, 62 Atl. 286 (rg05); State v. Martin, 77 N. J. L. 652, 73 Atl. 548 (rgog), aff'g 76 N. J. L. 292, 69 Aitl. rogr (Sup. Ct., 1908). 
The criminal codes of at least $\mathrm{I} 2$ states $^{49}$ contain provisions that the doing of any act prohibited by a statute and for which no other penalty is provided shall constitute a misdemeanor. These provisions are obscure but they present broad possibilities. Most loan sharks in the course of their activities perform acts which are prohibited although unpenalized. In jurisdictions having such general misdemeanor statutes, almost every loan shark contract may involve separate crimes and perhaps separate penalties before it has been fully collected. The cumulative results may be rendered grave for the offender.

Many loan sharks exert pressure on delinquent borrowers by sending to them documents fraudulently simulating judicial process such as summonses, or writs of garnishment or attachment. Such acts are criminal under the laws of some states. ${ }^{50}$ Also, the act of sending material of this nature through the mails with intent to deceive a debtor has been held to constitute the federal crime of using the mails to defraud. .1 $^{\text {.1 }}$

An illegal lender may also subject himself to criminal liability under the federal postal fraud laws $s^{52}$ under other circumstances. Any use of the postal facilities may have that result when the method of doing business involves deception of borrowers. It is not essential that the particular scheme shall have proved successful. The intended victim need not actually have been misled. It is not essential that the material sent through the mails itself contain anything fraudulent or deceptive. Any use of the mails, no matter how innocuous in itself, constitutes such an offense if it is in furtherance of a scheme to defraud..$^{53}$

Any lending scheme which involves a direct or implied misrepresentation or concealment of the true principal amount of a loan, of the fact that a lending transaction is a loan, or of the validity or enforceability of a contract, may constitute a fraudulent scheme within the meaning of the postal fraud laws. Any use of the mails in connection with carrying on a lending business of this character, even if confined to routine correspondence between headquarters and branch loan offices, may constitute a use of the mails in furtherance of a fraudulent scheme. In a case previously referred to, the activities of a collection agency in attempting to collect money not legally owing by sending through the mails material designed to create the false impression that a legally enforceable obligation existed were held to constitute the crime of using the mail to defraud. ${ }^{54}$

"Ariz., Ark., Idaho, Ill., Mich., Minn., Mont., Nev., N. Y., Okla., Tenn., and Wash.

${ }^{20}$ See, for example, ILI. AnN. Stat. (Smith Hurd, 1934) c. 38, \$323.

${ }^{82}$ Lesselyoung v. United States, I8 F. (2d) 472 (C. C. A. 8th, I927), cert. denied, 275 U. S. 535.

${ }^{52} 18 \mathrm{U}$. S. C. A. $\$ 5338,339$. The efficacy of this remedy is enhanced by the drastic nature of the penalties and by the fact that it eliminates much of the effectiveness of the common practice of avoiding penalties by crossing state lines.

${ }^{83}$ For an excellent treatise on the subject of postal frauds, see Tayzor, Postal Frauds and Crimes (x931).

E' Supra note 5I. Much of the language of the court is directly applieable to the typieal loan shark scheme aimed at the gullible and the ignorant. For example, in refutation of the contentions that no fraud had been practiced because the scheme would not have misled persons of average intelligence and because the misrepresentations were of law and not of fact, the court said: "It is sufficient if the purpose 
Certain weapons exist for the most part independent of statutes. The first of these is suggested by the foregoing discussion of postal frauds. The same common misrepresentations which are involved in the federal crime may also create rights of rescission and redress in damages on the part of the borrower on the ground of fraud, ${ }^{55}$ or subject the lender to criminal penalties on the same ground under the laws of a few states. ${ }^{56}$

Actions for slander, libel, malicious prosecution, or abuse of process may be maintained where as a result of attempts to collect from relatives or others the borrower's credit or personal standing has been impaired, where suit has been wrongfully instituted upon an alleged debt not legally owing, or where the borrower has been discharged or otherwise injured through unlawful garnishment. ${ }^{\text {. }}$

Probably the two most effective weapons available against loan sharks are those of injunction at the suit of the state and the action of quo warranto, including remedies incidental thereto such as the appointment of a receiver to aid in securing compliance with the injunction or the order of ouster.

Quo warranto is applicable only against corporate loan sharks. Where.applicable it affords much the same type of relief as that afforded by an injunction. The corporate defendant may be ousted from the further exercise of its charter privileges ${ }^{58}$ or may be ousted merely from exercising its corporate powers in an unlawful manner. ${ }^{59}$ Especially in the latter case the decree of ouster is in substance and generally in form also an injunction. A small loan licensee has been ousted from its charter privileges among other reasons because of its continued exaction of excessive charges. ${ }^{60}$

In the article on injunction and receiverships elsewhere in this symposium, the

was to defraud any person or persons whomsoever. The scheme was leveled against those most vulnerable to deception and naturally was less likely to succeed with people of highest intelligence or broadest experience.

“. . The maxim, that ignorance of the law does not excuse, has no application here. . . So the general rule that a fraudulent representation, to be available must be of fact and not of law, is subject to exception. This is especially true in a case of this nature. Deception under certain circumstances may be practiced upon the unsophisticated and unwary, even though the representation made involves law as well as fact. Particularly is this true when it is an insidious one, consisting of a series of plausible statements, calculated by their insistence to break down the feeble judgment of those to whom they are made, and gradually to inspire belief and acceptance. The demurrer to the indictment was therefore properly overruled."

${ }^{55}$ WeBB, LAW OF UsURY (1899) $5342 . \quad{ }^{10}$ See 27 CoRpus JURIs 110 et seq.

${ }^{57}$ See Liversage v. Gibson, 222 Ala. 672, 133 So. 715 (1931); Hardy v. Lewis Automobile Company, 297 S. W. 169 (Mo. App., 1927); and Adair v. James M. Peterson Bank, 6I Utah I59, 2ri Pac. 683 (1922).

For a vivid description of the extent to which the process of garnishment has veen abused in justice of the peace courts in oppressing large numbers of small borrowers, see Shaw v. Fox, supra note 7.

${ }^{38}$ See Trust Co. of Georgia v. State, supra note 13; State ex rel. Spillman, Att'y Gen. v. Central Purchasing Co., $118 \mathrm{Neb}$. 383,225 N. W. 46 (1929); Stockton v. Central R. of New Jersey, 50 N. J. Eq. 52, 24 Atl. 964 (I892); Commonwealth v. Banks, I98 Pa. 397, 48 Atl. 277 (1901), aff'g 9. Pa. Dist. R. 436 (1900); Att'y Gen. v. Railroad Companies, 35 Wis. 425 (1874).

${ }^{80}$ See People v. Toledo, etc., R. R., 280 Ill. 495, II7 N. E. 70I (1917), State v. Portland Natural Gas Co., 153 Ind. 483, 53 N. E. I089 (1899); State v. Old Town Bridge Corp., 85 Me. 17, 26 Atl. 947 (1892); Malone v. New York, etc. R. R., 197 Mass. 194, 83 N. E. 408 (1908).

${ }^{\circ 0}$ See State ex rel. v. Family Loan Co., supra note 6. 
marked advantages of equitable relief of this type as contrasted with other remedies, are demonstrated. Upon an appropriate showing, such equitable relief may properly be granted against a loan shark.61 This form of relief extends to the prevention of public injuries. The court may thus not only enjoin the making of future usurious loan contracts but, equally important, it may minimize the damaging effects of past illegal transactions by enjoining the collection of the contracts resulting therefrom. In order to insure obedience to the latter mandate, the existing contracts may be ordered impounded under the control of an officer of the court. From the loan shark's point of view, this relief is equitable and free of harshness because it imposes no criminal punishment.

In summation, any program of law enforcement designed to achieve maximum results in the small loan field requires a proper appreciation of several important factors. One is the extent of the injury to the public welfare which results from the exploitation of individual borrowers, the degree of helplessness of these borrowers, and the consequent need for action by public agencies if the public welfare is to be protected. Another is the inadequacy of usury laws and the consequent necessity to resort to remedies provided by laws of other types. Still another is the necessity to concentrate upon removing the inducement for making illegal small loans by eliminating the prospect of profit therefrom and by so enlarging the risk of criminal consequences as to overcome the desire for those profits. And further, there is the necessity to comprehend and to expose the true purpose of the innumerable devices employed by illegal lenders to avoid the impact of the laws which they violate.

${ }^{61}$ See the authorities cited in the article by Field, Injunction and Receivership Proceedings Against Illegal Lenders, infre p. 100. 